\title{
PERAN KEPRIBADIAN DALAM MEMEDIASI KETERLIBATAN ORANG TUA DENGAN EFIKASI DIRI PENGAMBILAN KEPUTUSAN KARIER
}

\author{
Rossi Galih Kesuma, Dwi Yuwono Puji Sugiharto, Sunawan \\ Program Studi Bimbingan dan Konseling Pascasarjana Universitas Negeri Semarang \\ E-mail:rossi.s2bk@students.unnes.ac.id/085647892277
}

\begin{abstract}
ABSTRAK
Penelitian ini bertujuan untuk mengetahui hubungan keterlibatan orang tua terhadap efikasi diri pengambilan keputusan karier yang dilakukan pada sampel yang terlibat sebanyak 400 peserta didik yang dipilih menggunakan teknik Cluster Random Sampling. Hipotesis penelitian ini bahwa neuroticism dan extraversion memediasi hubungan antara keterlibatan orang tua dengan efikasi diri pengambilan keputusan karier. Metode pengumpulan data menggunakan skala psikologi yang diadaptasi. Metode analisis data yang digunakan adalah analisis deskriptif dan analisis mediasi dengan teknik bootstrap bias corrected method dengan confidential interval $95 \%$. Hasil penelitian menunjukkan bahwa keterlibatan orang tua memprediksi efikasi diri pengambilan keputusan karier dan extraversion, namun tidak dapat memprediksi neuroticism,sedangkan neuroticism dapat memprediksi efikasi diri pengambilan keputusan karier, selanjutnya extraversion memediasi hubungan keterlibatan orang tua dengan efikasi diri pengambilan keputusan karier. Penelitian ini memberikan pemahaman bagi konselor mengenai hubungan keterlibatan orang tua serta pengaruh aspek personal (efikasi diri dankepribadian) dalam pemilihan karier.
\end{abstract}

Kata Kunci: Keterlibatan Orang Tua; Efikasi Diri Pengambilan Keputusan Karier; Neuroticism; Extraversion.

\begin{abstract}
This study aims to determine the relationship of parental involvement to career decision making self-efficacy carried out in the sample involved as many as 400 students selected using cluster random sampling technique. The hypothesis that neuroticism and extraversion mediate the relationship between parental involvement and career decision makingself-efficacy. Methods of data collection using an adapted psychological scale. Data analysis method used is descriptive analysis and mediation analysis with corrected method bias bootstrap technique with $95 \%$ confidential intervals. The results showed that parental involvement predicts career decision making self-efficacy and extraversion, but cannot predict neuroticism, while neuroticism can predict the career decision makingself-efficacy, furthermore extraversion mediates the relationship of parental involvement with career decision making self-efficacy. This study provides counselors with an understanding of the relationship of parental involvement and the influence of personal aspects (self-efficacy and personality) in career selection.
\end{abstract}

Keywords: Parents Involvement; Career Decision Making Self Efficacy; Neuroticism; Extraversion.

Dipublikasikan Oleh :

UPT Publikasi dan Pengelolaan Jurnal

Universitas Islam Kalimantan Muhammad Arsyad Al-Banjari Banjarmasin 


\section{PENDAHULUAN}

Zunker (2006:38) menjelaskan bahwa kunci utama dalam proses pengambilan keputusan karier adalah pemecahan masalah dan keterampilan dalam membuat keputusan. Masa Sekolah Menengah Pertama (SMP) merupakan masa yang sangat penting untuk mempersiapkan dan menentukan karier. Pada masa ini, peserta didik mulai menentukan nasib untuk tiga atau empat tahun mendatang yaitu memilih sekolah hingga jurusan di jenjang sekolah yang lebih tinggi (SMA/SMK). Lebih lanjut dari hasil permantapan ini tentunya akan berdampak pada keputusan karier saat peserta didik tersebut masuk masa perkuliahan kelak dan berbagai langkah dalam mewujudkan cita-citanya.

Namun kenyataannya tidak semua peserta didik mampu membuat keputusan karier yang tepat.Yulius (2014) dalam studi kasus kemantapan pengambilan keputusan karier peserta didik kelas IX di SMP N 9 Salatiga diperoleh bahwa $70 \%$ peserta didik memiliki kemantapan karier yang masih dalam tahap pengembangan (growth). Sedangkan Purnamasari (2015)menyatakan bahwa kematangan karier peserta didik kelas VIII SMP Islam Sudirman Ambarawa berada pada kualifikasi kematangan karier yang rendah, sehingga diperlukan bimbingan karier untuk kematangan karier peserta didik.

Berdasarkan survei yang telah dilakukan pada peserta didik SMP dan SMA terkait persiapan rencana studi dan pilihan universitas (pendidikan tinggi lanjutan) diketahui bahwa sebanyak $45,12 \%$ peserta didik menyatakan tidak terlalu yakin akan pilihan sekolah lanjutan mereka. Di samping itu, dalam mencari informasi mengenai sekolah lanjutan, peserta didik lebih banyak mencari informasi mengenai sekolah lanjutan dari internet, yakni sebesar 58,21\%, dibandingkan mencari informasi dari pihak lain, seperti orang tua, kakak kelas, maupun pihak sekolah (Rina, 2015). Selain itu, internet memiliki pengaruh yang cukup besar dalam pemilihan jurusan di universitas kelak, yakni sebesar 57,14\%, dibandingkan dengan pengaruh orang tua yang hanya sebesar $25,40 \%$.

Sementara temuanAli \& Mukhibat (2016) menyatakan bahwa peran keluarga dalam hal ini orang tua terkait dengan harapan akan hasil, yang meliputi dukungan instrumental, dukungan model, dukungan lisan, dan dukungan emosional memiliki pengaruh yang positif dan signifikan terhadap efikasi diri pengambilan keputusan karier peserta didik. Temuan lain juga menyatakan bahwa penghambat dalam pemilihan sekolah lanjutan peserta didik adalah faktor internal, mengenai kondisi fisik dan psikis peserta didik, dan faktor eksternal yang meliputi kondisi keluarga, kondisi sekolah, dan kondisi teman (Widiawati \& Setyowani, 2016).
Terdapat empat faktor yang memengaruhi pengambilan keputusan karier peserta didik, yakni pribadi, kelompok (keluarga), lingkungan sekolah, dan eksplorasi karier(Su, Chang, Wu, \& Liao, 2016). Faktor pribadi merupakan faktor yang sangat berpengaruh terhadap pengambilan keputusan karier, dilanjutkan faktor kelompok (keluarga), faktor eksplorasi karier, dan faktor sekolah berada pada level terendah yang memengaruhi pengambilan keputusan karier peserta didik.

Kepribadian memiliki peran besar dalam kemampuan pengambilan keputusan karier(Alkalbani, Salleh, \& Mastor, 2011; Gati et al., 2011; Pečjak \& Košir, 2007; Wang, Jome, Haase, \& Bruch, 2006). Kepribadian neuroticism berpengaruh kuat dan positif terkait efikasi diri pengambilan keputusan karier, kesulitan pengambilan keputusan karier dikarenakan individu mengalami ketidakstabilan emosional dan psikologis. Kepribadian extraversion disebutkan bahwa individu yang lebih ramah dan aktif lebih kecil kemungkinannya dalam mengalami kesulitas pengambilan keputusan karier, bisa dikatakan efikasi diri individu yang lebih ramah dan aktif lebih tinggi dalam pengambilan keputusan kariernya(Gati et al., 2011). Sementara Wang et al. (2006)dalam penelitiannya yang menempatkan neuroticism dan extraversion sebagai variabel laten menyebutkan bahwa pada mahasiswa kulit putih, efikasi diri pengambilan keputusan karier "fully mediated" pada hubungan antara kepribadian dengan komitmen karier, sedangkan pada mahasiswa nonkulit putih hanya "partly mediated".

Pilihan karier individu bisa lebih berhasil diwujudkan melalui pemahaman kepribadian (Lei, 2013). Dengan memahami tipe kepribadian individu kita bisa membantu individu untuk mengembangkan potensinya secara tepat dan optimal.

Faktor lain yang memengaruhi efikasi diri pengambilan keputusan karier adalah faktor kontekstual atau faktor lingkungan, misalnya keterlibatan orang tua, cultural misstrust, dan harapan akan masa depan (Rogers, Creed, \& Glendon, 2008; Bullock-Yowell, Andrews, \& Mary E. Buzzetta, 2011;Penn, 2016). Keterlibatan orang tua khususnya mengenai dukungan karier pada peserta didik, termasuk sebagai pengaruh dari sumber-sumber efikasi diri pengambilan keputusan karier.

Dukungan dan keterlibatan orang tua berperan positif terhadap kemampuan seseorang dalam mengambil keputusan karier dan beradaptasi dalam karier (Guan et al., 2016). Sementara Xing (2016) dalam penelitian disertasinya mengemukakan bahwa dukungan/keterlibatanorang tua dalam menunjukkan harapan yang tinggi bagi remaja akan karier lebih penting untuk pengembangan karier mereka daripada 
interaksi spesifik seperti menawarkan informasi eksplisit tentang karier.

Aspirasi orang tua terhadap anak, prestasi belajar, dan karakteristik kepribadian memiliki pengaruh yang tinggi pada eksplorasi karier peserta didik(Purwanta, 2011). Oleh karena itu, dalam penyusunan dan pelaksanaan bimbingan karier di sekolah hendaknya melibatkan peran orang tua serta dibutuhkannya asesmen kepribadian.

Tujuan dari penelitian untuk menguji hubungan antara keterlibatan orang tua dengan efikasi diri pengambilan keputusan karier peserta didik SMP dengan dimediasi oleh neuroticism dan extraversion. Sebagian besar penelitian mengenai efikasi diri pengambilan keputusan karier pada peserta didik yang telah diteliti sebelumnya, berkisar pada usia SMA atau bahkan mahasiswa perguruan tinggi. Sedangkan peneliti bermaksud meneliti ditingkat usia SMP. Hal ini dikarenakan, semakin dini individu memiliki efikasi diri yang baik, kelak diusia dewasanya, tidak lagi ada kebimbangan dan keraguan dalam menatap masa depannya.

\section{METODE}

Penelitian ini menggunakan metode kuantitatif dengan desain korelasional ex-post facto dengan sampel peserta didik SMP di Kota Semarang yang berjumlah 400 siswa yang diambil menggunakan teknik Cluster Random Sampling. Kota Semarang terdiriatas 16 kecamatan, dan diambil 1 sekolah untuk tiap kecamatannya.

\section{Pengukuran}

Variabel dalam penelitian ini meliputi efikasi diri pengambilan keputusan karier (Y), keterlibatan orang tua (X), serta neuroticism dan extraversion (M). Untuk memperoleh data dalam penelitian ini, peneliti menggunakan inventori skala psikologi untuk mengungkap konstruk psikologi yang sedang diukur.

Seluruh instrumen yang digunakan diproses melalui proses back translation. Hal tersebut terkait transformasi teks dari satu bahasa ke bahasa lain (Iliescu, 2018). Penerjemahan pertama menerjemahkan semua skala dari bahasa Inggris ke bahasa Indonesia, kemudian penerjemahan kedua menerjemahkan dari skala versi Indonesia ke Bahasa Inggris (Nababan, Nuraeni, \& Sumardiono, 2012). Perbedaan hasil penerjemahan kembali dibahas dan disesuaikan dengan terjemahan Bahasa Indonesia.

\section{Efikasi Diri Pengambilan Keputusan Karier}

Untuk mengukur efikasi diri pengambilan keputusan karier dari siswa, menggunakan instrument adaptasi dari Career Decision Making Self EfficacyShort Form (CDMSE-SF) yang terdiri dari 25 item dikembangkan dari 5 indikator, yaitu self-appraisal, occupational information, goal selection, planning, dan problem solving. Interpretasi nilai skala efikasi diri menggunakan skala Likert, yaitu 1 (tidak yakin) hingga5 (sangat yakin sekali). Reliabilitas instrumen ini menggunakan Cronbach Alpha sebesar .752.

\section{Keterlibatan Orang Tua}

Parent Career Behavior Checklist (PCBC) digunakan untuk mengetahui pandangan atau persepsi peserta didik akan hubungan antara peserta didik dan orang tuanya. Pernyataan-pernyataan di dalam skala ini akan mengungkap pandangan peserta didik tentang sejauh mana peran orang tua dalam hubungannya dengan perkembangan anak-anak mereka. Terdiri atas 23 butir. Interpretasi nilai persetujuan tersebut menggunakan skala Likert, mulai dari tidak pernah (1) hingga sangat sering (5). Reliabilitas instrument ini menggunakan Cronbach Alpha sebesar .751.

\section{Extraversion}

Untuk mengukur extraversion digunakan instrumen adaptasi dari Big Five Personality Inventory. Terdiri atas 10 item pernyataan untuk mengindikasikan tingkat persetujuan mereka atas keadaan diri mereka sendiri. Interpretasi nilai persetujuan tersebut menggunakan skala Likert, yaitu 1 (tidak setuju sama sekali) sampai dengan 5 (sangat setuju sekali). Reliabilitas instrument ini menggunakan Cronbach Alpha sebesar .641.

\section{Neuroticism}

Untuk mengukur neuroticism digunakan instrumen adaptasi dari Big Five Personality Inventory. Terdiri atas 10 item pernyataan untuk mengindikasikan tingkat persetujuan partisipan atas keadaan diri mereka sendiri. Interpretasi nilai persetujuan tersebut menggunakan skala Likert, yaitu 1 (tidak setuju sama sekali) sampai dengan 5 (sangat setuju sekali). Reliabilitas instrument ini menggunakan Cronbach Alpha sebesar .720.

\section{Prosedur pengumpulan dan analisis data}

Proses penelitian dengan mengumpulkan data dari peserta didik yang menjadi partisipan. Pengumpulan data dilakukan saat jam pelajaran dengan meminta siswa mengisi tiga skala, yakni skala efikasi diri pengambilan keputusan karier, skala openness, dan skala parents career behaviour checklist. Jawaban siswa yang terkumpul selanjutnya ditabulasi dan dianalisis.

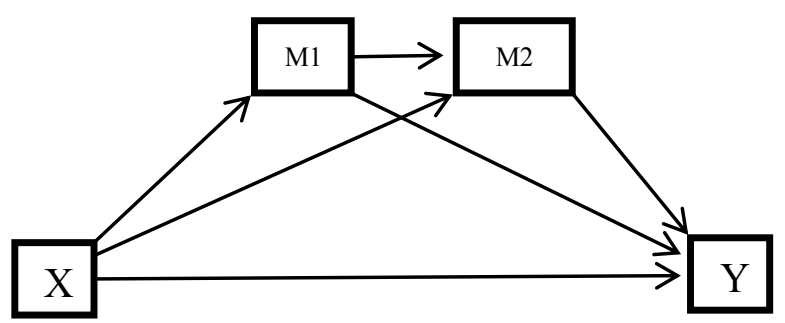

Gambar 1 Conceptual Diagram Model Templates

Dipublikasikan Oleh :

UPT Publikasi dan Pengelolaan Jurnal

Universitas Islam Kalimantan Muhammad Arsyad Al-Banjari Banjarmasin 
Tabel 1. Matrik Interkorelasi

\begin{tabular}{|c|c|c|c|c|c|c|c|c|}
\hline & $\begin{array}{l}\text { Keterlibatan } \\
\text { Orang Tua }\end{array}$ & $\begin{array}{l}\text { Extra- } \\
\text { version }\end{array}$ & $\begin{array}{l}\text { Neuro- } \\
\text { ticism }\end{array}$ & $\begin{array}{l}\text { Self } \\
\text { Appraisal }\end{array}$ & $\begin{array}{l}\text { Occupational } \\
\text { Information }\end{array}$ & $\begin{array}{l}\text { Goal } \\
\text { Selection }\end{array}$ & $\begin{array}{l}\text { Making } \\
\text { Plans }\end{array}$ & $\begin{array}{l}\text { Problem } \\
\text { Solving }\end{array}$ \\
\hline $\begin{array}{l}\text { Keterlibatan } \\
\text { Orang Tua }\end{array}$ & 0 & - & - & - & 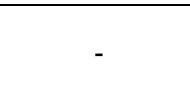 & 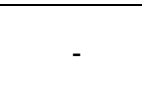 & - & - \\
\hline Extraversion & .21 & - & - & - & - & - & - & - \\
\hline Neuroticism & .08 & .26 & - & - & - & - & - & - \\
\hline Self Appraissal & .36 & .32 & .24 & - & - & - & - & - \\
\hline $\begin{array}{l}\text { Occupational } \\
\text { Information }\end{array}$ & .41 & .31 & .13 & .68 & - & - & - & - \\
\hline Goal Selection & .36 & .32 & .22 & .74 & .71 & - & - & - \\
\hline Making Plans & .34 & .25 & .10 & .72 & .72 & .72 & - & - \\
\hline $\begin{array}{l}\text { Problem } \\
\text { Solving }\end{array}$ & .28 & .27 & .15 & .67 & .63 & .65 & .67 & - \\
\hline Rata-rata & 76.47 & 30.96 & 31.29 & 17.69 & 16.78 & 17.36 & 16.98 & 16.34 \\
\hline SB & 15.17 & 4.30 & 5.64 & 3.12 & 3.45 & 3.24 & 3.39 & 3.15 \\
\hline
\end{tabular}

Sumber: data diolah, 2018

Analisis data dilakukan dengananalisis mediasi yang dikembangkan oleh Andrew F. Hayes (2013) dengan menggunakan perangkat lunak SPSS versi 24 Process v3.0 (IBM Corp., 2017). Analisis data dengan menguji uji asumsi klasik, yang terdiri atas uji normalitas, uji multikolinieritas, uji heteroskedastisitas, dan uji linieritas; dan uji hipotesis. Pada pengujian hipotesis, analisis mediasi menggunakan teknik bias corrected, bootstraping $\mathrm{N}=5000$, dengan confidential interval $95 \%$. Penelitian ini menggunakan template model nomor 6 yang terdiri dari 1 variabel dependen (efikasi diri pengambilan keputusan karier), 1 variabel independen (keterlibatan orang tua), dan 2 variabel mediator (neuroticism dan extraversion). Analisis ini akan menemukan hasil tentang empat jalur pengaruh antarvariabel, yakni pengaruh langsung antara $\mathrm{X}$ (keterlibatan orang tua) dengan Y (efikasi diri pengambilan keputusan karier) dan juga efek tidak langsung pengaruh $\mathrm{X}$ dan $\mathrm{Y}$ melalui $\mathrm{M}_{1}$ (Extraversion) dan $\mathrm{M}_{2}$ (Neuroticism). Adapun model analisis data dalam penelitian ini dapat dilihat pada gambar 1 .

\section{HASIL DAN PEMBAHASAN}

Tingkat rata-rata dan SD setiap variabel dalam penelitian ini dan hubungan antar semua variabel dapat dilihat dalam matriks interkorelasi sebagaimana disajikan dalam Tabel 1. Dilihat dari rata-rata, para peserta didik cenderung memiliki tingkat efikasi diri pengambilan keputusan karier yang tinggi. Hal tersebut dapat dilihat dari nilai rata-rata setiap dimensi dari efikasi diri pengambilan keputusan karier, yang meliputi self appraisalyang memiliki nilai tertinggi, dilanjutkan goal selection, making plans, occupational information, dan ditingkat yang paling rendah diantara dimensi efikasi diri pengambilan keputusan karier, problem solving. Tingkat extraversion peserta didik pada kepribadiannnya dalam kategori sedang, dan tingkat neuroticism peserta didik dalam kategori hampir mencapai baik sedangkan tingkat keterlibatan orang tua pada perkembangan karier peserta didik dalam kategori baik. Tabel 2 menunjukkan bahwa secara umum terdapat hubungan antara efikasi diri pengambilan keputusan karier dengan extraversion dan neuroticism, serta extraversion dan neuroticism dengan keterlibatan orang tua.

Sementara Tabel 2 menunjukkan bahwa secara umum terdapat hubungan antara efikasi diri pengambilan keputusan karier dengan keterlibatan orang tua melalui mediasi extraversion dan neuroticism.Dari hasil pengolahan data menunjukkan bahwa ada prediksi positif mengenai hubungan keterlibatan orang tua dengan dimensi-dimensi efikasi diri pengambilan keputusan karier berturut-turut $(\beta=$ $0,06,0,08,0,07,0,07,0,05 ; \mathrm{t}_{(383)}=6,51,7,87,6,58$, $6,36,4,80 ; p<0,01)$, dan dengan extraversion $(\beta=0,05$; $\left.\mathrm{t}_{(382)}=3,95 ; \mathrm{p}<0,01\right)$. Sementara antara keterlibatan orang tua dengan neuroticism $\left(\beta=0,03 ; \mathrm{t}_{(383)}=1,57\right.$; $\mathrm{p}>0,05)$ menunjukkan hasil yang tidak signifikan. Selanjutnya, hasil menunjukkan prediksi positif hubungan langsung yang signifikan antara extraversion dengan efikasi diri pengambilan keputusan karier peserta didik SMP yang terdiri atas lima dimensi berturut-turut $(\beta=0,09,0,03,0,08,0,02$, 0,$\left.04 ; \mathrm{t}_{(381)}=3,39,0,96,2,92,0,60,1,61 ; \mathrm{p}<0,01\right)$. Namun hasil berbeda ditunjukkan hubungan langsung

\section{Dipublikasikan Oleh :}

UPT Publikasi dan Pengelolaan Jurnal

Universitas Islam Kalimantan Muhammad Arsyad Al-Banjari Banjarmasin 
antara neuroticism dengan dimensi-dimensi efikasi diri pengambilan keputusan karier peserta didik SMP berturut-turut $\left(\beta=0,16,0,18,0,17,0,14,0,15 ; \mathrm{t}_{(381)}=\right.$ $4,54,4,56,4,56,3,63,4,04 ; \mathrm{p}<0,01$ dan $\mathrm{p}>0,05)$, dimana neuroticism memiliki hubungan positif yang signifikan denganself appraisal dan goal selection, namun memiliki hubungan yang negatif dengan occupational information, making plans, dan problem solving. Kemudian, penelitian ini menunjukkan peran extraversion dan neuroticism sebagai mediator antara keterlibatan orang tua dengan efikasi diri pengambilan keputusan karier peserta didik SMPsecara berturut- turut $(\beta=0,01, \mathrm{SE}=0,01, \mathrm{p}<0,01)$. Dalam hal ini antara jalur almenuju jalur b1 dan c' dapat dikatakan signifikan, $(p<0.01)$, dengan kata lain terdapat pengaruh hubungan yang signifikan keterlibatan orang tua dengan efikasi diri pengambilan keputusan karier yang dimediasi extraversion. Sementara antara jalur a2 menuju jalur b2 dapat dikatakan tidak signifikan, ( $p>0.05)$, dengan kata lain tidak terdapat pengaruh hubungan yang signifikan keterlibatan orang tua dengan efikasi diri pengambilan keputusan karier yang dimediasi neuroticism. Hasil penelitian dapat dilihat pada gambar 2 .

Tabel 2. Analisis Hasil Regresi dan Mediasi Variabel

\begin{tabular}{|c|c|c|c|c|c|c|c|c|c|c|}
\hline Predictor & $\boldsymbol{\beta}$ & $\mathrm{t}$ & $P$ & SE & $\begin{array}{l}\text { LLCI } \\
(95 \%)\end{array}$ & $\begin{array}{c}\text { ULCI } \\
(95 \%)\end{array}$ & $\mathbf{R}$ & $\mathrm{R}^{2}$ & $F$ & $\mathrm{p}$ \\
\hline Outcome $E_{X}$ & & & & & & & .33 & .11 & 22.57 & $<.01$ \\
\hline KO & .05 & 3.95 & $<.01$ & .01 & .03 & .08 & & & & \\
\hline $\mathrm{Neu}$ & .19 & 5.10 & $<.01$ & .04 & .12 & .26 & & & & \\
\hline Outcome Neu & & & & & & & .08 & .01 & 2.46 & $>.05$ \\
\hline KO & .03 & 1.57 & $>.05$ & .02 & -.01 & .07 & & & & \\
\hline Outcome $S A$ & & & & & & & .47 & .22 & 35.26 & $<.01$ \\
\hline KO & .06 & 6.51 & $<.01$ & .01 & .04 & .08 & & & & \\
\hline Ex & .16 & 4.54 & $<.01$ & .04 & .09 & .23 & & & & \\
\hline $\mathrm{Neu}$ & .09 & 3.39 & $<.01$ & .03 & .04 & .14 & & & & \\
\hline Outcome OI & & & & & & & .47 & .22 & 36.45 & $<.01$ \\
\hline KO & .08 & 7.87 & $<.01$ & .01 & .06 & .10 & & & & \\
\hline Ex & .18 & 4.56 & $<.01$ & .04 & .10 & .25 & & & & \\
\hline $\mathrm{Neu}$ & .03 & .96 & $>.05$ & .03 & -.03 & .08 & & & & \\
\hline Outcome $G S$ & & & & & & & .46 & .21 & 34.16 & $>.05$ \\
\hline KO & .07 & 6.58 & $<.01$ & .01 & .05 & .09 & & & & \\
\hline Ex & .17 & 4.56 & $<.01$ & .04 & .09 & .24 & & & & \\
\hline $\mathrm{Neu}$ & .08 & 2.92 & $<.01$ & .03 & .03 & .13 & & & & \\
\hline Outcome $M P$ & & & & & & & .39 & .16 & 23.29 & $<.01$ \\
\hline KO & .07 & 6.36 & $<.01$ & .01 & .05 & .09 & & & & \\
\hline Ex & .14 & 3.63 & $<.01$ & .04 & .07 & .22 & & & & \\
\hline $\mathrm{Neu}$ & .02 & .60 & $>.05$ & .03 & -.04 & .07 & & & & \\
\hline Outcome PS & & & & & & & .37 & .13 & 19.71 & $<.01$ \\
\hline KO & .05 & 4.80 & $<.01$ & .01 & .03 & .07 & & & & \\
\hline Ex & .15 & 4.04 & $<.01$ & .04 & .08 & .22 & & & & \\
\hline $\mathrm{Neu}$ & .04 & 1.61 & $>.05$ & .03 & -.01 & .10 & & & & \\
\hline TE SA & .06 & 6.51 & $<.01$ & .01 & .04 & .08 & & & & \\
\hline TE OI & .08 & 7.87 & $<.01$ & .01 & .06 & .10 & & & & \\
\hline TE GS & .07 & 6.58 & $<.01$ & .01 & .05 & .09 & & & & \\
\hline TE MP & .07 & 6.36 & $<.01$ & .01 & .05 & .09 & & & & \\
\hline TE PS & .05 & 4.80 & $<.01$ & .01 & .03 & .07 & & & & \\
\hline IE SA & .01 & & $<.01$ & .01 & .01 & .02 & & & & \\
\hline IE OI & .01 & & $<.01$ & .01 & .01 & .02 & & & & \\
\hline IE GS & .01 & & $<.01$ & .01 & .01 & .02 & & & & \\
\hline IE MP & .01 & & $<.01$ & .01 & .01 & .02 & & & & \\
\hline IE PS & .01 & & $<.01$ & .01 & .01 & .02 & & & & \\
\hline
\end{tabular}

Keterangan:

Ex: Extraversion; Neu: Neuroticism; SA: self appraisal; OI: Occupational Information; GS: Goal Selection; MP: Making Plans; PS: Problem Solving; PI: parents involvement/keterlibatan orang tua; TE: total effect; IE : indirect effect

Dipublikasikan Oleh :

UPT Publikasi dan Pengelolaan Jurnal

Universitas Islam Kalimantan Muhammad Arsyad Al-Banjari Banjarmasin 


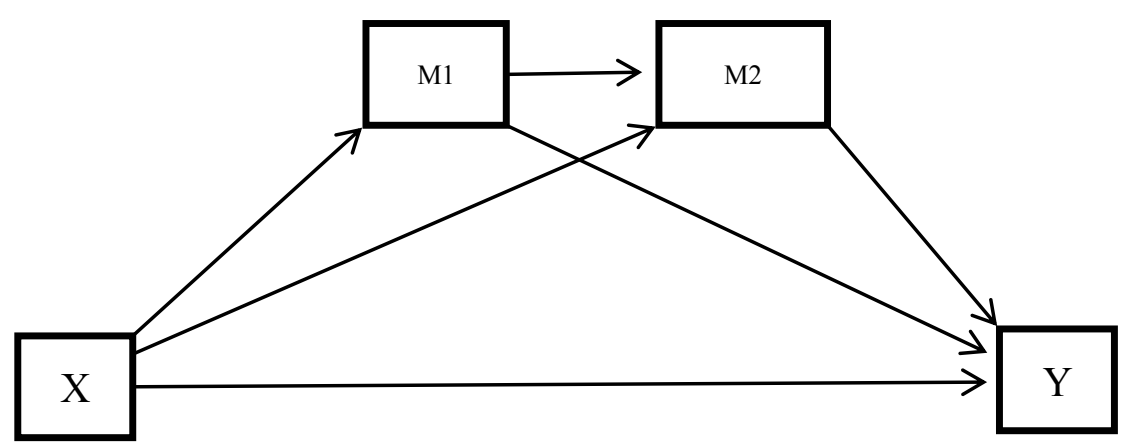

Gambar 2. Hasil Olah Data

Hasil ini senada dengan temuan Guan et al. (2016)mengenai peran dukungan orang tua terhadap efikasi diri pengambilan keputusan karier dan adaptasi karier. Penelitian tersebut menunjukkan adanya peran dari dukungan orang tua terhadap kemampuan seseorang dalam mengambil keputusan karier dan beradaptasi dalam karier secara positif. Dalam penelitian ini, subjek penelitian yang digunakan adalah peserta didik Sekolah Menengah Pertama, dengan hasil penelitian yang menyatakan bahwa keterlibatan orang tua, dalam dukungan secara umum maupun dukungan khusus mengenai karier, memiliki pengaruh yang signifikan terhadap tingkat efikasi diri pengambilan keputusan karier peserta didik.

Namun berbeda dengan temuan Fouad, Kim, Ghosh, Chang, \& Figueiredo (2016) yang menemukan bahwa 95\% responden menyatakan bahwa dukungan finansial orang tua, harapan orang tua, serta nilai dan beliefs dari keluarga memengaruhi efikasi diri dalam pengambilan keputusan karier mereka. Penelitian tersebut lebih banyak menyatakan mengenai kemampuan orang tua dalam memberikan pendidikan pada individu lebih memiliki pengaruh terhadap tingkat efikasi diri pengambilan keputusan karier seseorang.

Hasil penelitian ini juga didukung dengan teori Social Cognitive Career Theory (SCCT), yang menyatakan bahwa dukungan keluarga terutama orang tua, juga merupakan sumber verbal persuasion bagi efikasi diri pengambilan keputusan karier individu. Disamping itu, perhatian, dukungan, dan keterlibatan orang tua pada anak-anaknya, dipandang memberikan dukungan psychosocial bagi peserta didik.Penelitian ini dilakukan dengan mengambil sampling siswa dari 16 kecamatan di kota Semarang. Hal ini menyiratkan bahwa hasil penelitian ini mewakili dukungan orang tua dari berbagai latar belakang dan nilai keterlibatannya pada anak-anak mereka baik dalam dukungan secara umum maupun dukungan karier.
Peran keluarga sebagai suatuinstitusi harus menciptakan kondisi untuk pengembangan hubungan positif terhadap pekerjaan, yang merupakan predisposisi menuju pembentukan pendekatan realistis untuk pengembangan kepribadian individuberupa perilaku bawaan, minat, kecemasan, dan kegembiraan (Ceka \& Murati, 2016; Kuçuk, Habaci, Gokturk, Urker, \& Adiguzelli, 2012). Situasi ataupun pengalaman negatif yang diterima oleh individu akan membawa dampak pada negatifnya kepribadian yang dimiliki oleh individu tersebut. Demikian pula sebaliknya.

Sama halnya dengan temuan dari Kuçuk, Habaci, Gokturk, Urker, \& Adiguzelli (2012) yang mengemukakan bahwa pembentukan kepribadian yang muncul berupa perilaku bawaan, minat, kecemasan, dan kegembiraan dipengaruhi oleh keluarga, lingkungan sosial, dan situasi-situasi dan pengalaman-pengalaman baru yang memungkinkan individu untuk meletakkan dasar-dasar kepribadian, tidak peduli betapa sedikit perubahan yang mereka miliki. Hasil penelitian yang dilakukan menunjukkan bahwa situasi ataupun pengalaman negatif yang diterima oleh individu akan membawa dampak pada negatifnya kepribadian yang dimiliki oleh individu tersebut.

Keluarga memiliki fungsi afeksi dan rekreasi (Sayekti, 1994). Tumbuh kembang seseorang secara tidak langsung dipengaruhi oleh kasih sayang yang diberikan oleh keluarga (orang tua). Keluarga dapat pula berfungsi rekrekatif, dengan dapat berjumpa dengan keluarga, bercanda gurau dengan keluarga, berbagi kasih sayang adalah hal terindah dalam keluarga. Melalui kasih sayang, kebahagiaan, dan kenyamanan dalam keluarga, akan menumbuhkan tipe kepribadian individu secara positif. Ketidaknyamanan dan ketidakbahagiaan bisa membuat seseorang memiliki extraversion yang rendah dengan kepribadian yang pendiam, pemalu, suka bergaul, atau 
kepribadian introversion/introvert. Sedangkan saat individu tidak mendapat fungsi afeksi yang baik dari orang tua dan dalam keluarga, dapat menyebabkan individu memiliki kepribadian neuroticism yang tinggi, sehingga memiliki emosi yang tidak stabil.

Salah satu faktor yang memengaruhi efikasi diri pengambilan keputusan karier adalah faktor personal, seperti tipe kepribadian five factor model, gender, dan kecemasan(Bullock-Yowell et al., 2011).Efikasi diri pengambilan keputusan karier berkorelasi tinggi terhadap tipe kepribadian five factor model.Openness, conscientiousness, extraversion, dan agreeableness memiliki nilai positif yang tinggi terhadap efikasi diri pengambilan keputusan karier peserta didik. Sedangkan neuroticism, memiliki nilai negatif terhadap efikasi diri pengambilan keputusan karier. Senada dengan hal tersebut, temuan dalam penelitian ini memunculkan adanya hubungan positif yang signifikan antara extraversion dengan efikasi diri pengambilan keputusan karier peserta didik SMP, dan hubungan yang negatif antara neuroticism dengan efikasi diri pengambilan keputusan karier pesertadidik SMP.

Penelitian ini berbanding lurus dengan teori dan hasil penelitian yang ada, bahwa extraversion yang merupakan salah satu dari tipe kepribadian Big Five Personality memiliki hubungan yang positif dan signifikan dengan efikasi diri pengambilan keputusan karier, dan neuroticism memiliki korelasi yang negatif dengan efikasi diri pengambilan keputusan karier. Efikasi diri pengambilan keputusan karier merupakan keyakinan seseorang untuk dapat sukses dalam menilai diri dengan tepat, mengumpulkan informasi bidang kerja, menyeleksi tujuan, membuat perencanaan karier dan memecahkan permasalahan yang berkaitan dengan karier (Taylor \& Betz, 1983). Pengembangan kemampuan dan keterampilan efikasi diri dalam pengambilan keputusan karier bergantung pada tingkat kepribadian pada masing-masing individu. Dengan memiliki kepribadian yang positif, tentu diharapkan efikasi diri pengambilan keputusan karier individu juga akan tinggi.

Hal ini senada dengan temuan Bullock-Yowell et al. (2011) yang menyatakan bahwa terdapat empat sumber efikasi diri pengambilan keputusan karier individu, diantaranya (1) enactive mastery experience; (2) vicarious experience; (3) verbal persuasion; dan (4) physiological and affective states. Keterlibatan orang tua khususnya mengenai dukungan karier pada peserta didik, termasuk sebagai pengaruh dari sumbersumber efikasi diri pengambilan keputusan karier. Disamping itu, extraversion dan neuroticism yang merupakan bagian dari tipe kepribadian Big Five Theory merupakan suatu keadaan psikologis dan afeksi seseorang dalam efikasi diri pengambilan keputusan karier.

\section{PENUTUP}

Keterlibatan orang tua berkorelasi positif terhadap extraversion peserta didik SMP, namun berkorelasi negatif terhadap neuroticism peserta didik SMP. Hal ini berarti semakin tinggi tingkat keterlibatan orang tua akan karier pesertadidik, maka akan semakin tinggi pula extraversion peserta didik, namun semakin rendah neuroticism. Extraversion juga berpengaruh positif terhadap dimensi-dimensi efikasi diri pengambilan keputusan karier peserta didik SMP. Hal ini berarti semakin baik extraversion pesertadidik, maka akan semakin tinggi pula efikasi diri pengambilan keputusan karier peserta didik, yang meliputi self appraisal, occupational information, goal selection, making plans for the future, dan problem solving. Sementara neuroticism berkorelasi positif dengan self appraisal dan goal selection, namun berkorelasi negative dengan occupational information, making plans for the future, dan problem solving. Keterlibatan orang tuajugamemiliki pengaruh positif terhadap efikasi diri pengambilan keputusan karier peserta didik SMP. Hal ini berarti semakin tinggi tingkat keterlibatan orang tua akan karier peserta didik maka akan semakin tinggi pula efikasi diri pengambilan keputusan karier dari peserta didik.

Penelitian ini memberikan implikasi pada penerapan layanan bimbingan dan konseling karier di sekolah yakni memberikan pemahaman bagi konselor mengenai pengaruh konteks lingkungan (dalam hal ini keterlibatan orang tua) serta pengaruh aspek personal seseorang pada pembuatan keputusan karier, serta dampaknya pada pilihan, sikap, dan kepercayaan karier peserta didik. Berdasarkan temuan penelitian, pelayanan bimbingan dan konseling karier perlu untuk mengintegrasikan konteks personal dan keterlibatan orang tua untuk membantu peserta didik mengembangkan efikasi diri dalam mengambil keputusan karier peserta didik, serta untuk membantu peserta didik mencapai standar kompetensi kemandirian peserta didik utamanya dalam hal karier.

Oleh karenanya, konselor perlu memberikan pelayanan untuk dapat meningkatkan keterlibatan positif orang tua akan arah tujuan karier peserta didik. Selain itu, konselor perlu memberikan konseling karier secara holistik dan kontekstual pada peserta didik dengan beragam latar belakang keluarga. Konselor juga perlu mengembangkan program bimbingan dan konseling yang ditujukan untuk mengembangkan tipe kepribadian yang positif peserta didik dari beragam latar belakang keluarga, yang nantinya hal tersebut akan dapat mendukung proses pembuatan keputusan karier peserta didik.

Untuk peneliti selanjutnya harapannya dapat mengembangkan penelitian yang lebih dalam tentang efikasi diri pengambilan keputusan karier, baik dalam 
subjek penelitian maupun metode penelitian dengan menguji efektifitas dari program konseling karier yang dihasilkan untuk meningkatkan efikasi diri pengambilan keputusan karier peserta didik Sekolah Menengah Pertama. Selain itu dapat pula dikembangkan dengan pendekatan kuantitatif lainnya menggunakan analisis data yang berbeda, maupun dengan pendekatan kualitatif atupun juga mixed methods. Hal itu berkaitan dengan keterbatasan penelitian ini yang belum sepenuhnya mengungkap kajian keterlibatan orang tua untuk mengkaji variabel/konstruk psikologis yang sedang diteliti. Melalui pendekatan kualitatif atau mixed methods harapannya dapat membahas lebih mendalam utamanya pembahasan mengenai latar belakang sosiokultur, maupun sosioekonomi keluarga yang dikaitan dengan konstruk psikologis peserta didik. Serta masih sangat dimungkinkan penelitian selanjutnya meneliti hubungan tidak langsung variabel ketiga menggunakan model yang lain, misalnya model Structural Equation Model (SEM).

\section{REFERENSI}

Al-kalbani, M. S. A., Salleh, A., \& Mastor, K. A. (2011). Career Decision Making Constructs and Five-Factor Model in Adolescents Center for General Studies , 14(Cdmi), 34-39.

Ali, M., \& Mukhibat. (2016). Dukungan Keluarga , Peran Keputusan Karir, Dan Career Indecision Siswa Sekolah Madiun. Palastren, 9(2), 279 304.

Andrew F. Hayes. (2013). Introduction to Mediation, Moderation, and Conditional Process Analysis. London: Guilford Press.

Bullock-Yowell, E., Andrews, L., \& Mary E. Buzzetta. (2011). Explaining Career DecisionMaking Self-Efficacy: Personality, Cognitions , and Cultural Mistrust. The Career Development Quarterly, 59(September), 400-411.

Ceka, A., \& Murati, R. (2016). The Role of Parents in the Education of Children, 7(5), 61-64.

Fouad, N. A., Kim, S., Ghosh, A., Chang, W., \& Figueiredo, C. (2016). Family Influence on Career Decision Making. Journal of Career Assessment, 24(1), 197-212. https://doi.org/10.1177/1069072714565782

Gati, I., Gadassi, R., Saka, N., Hadadi, Y., Ansenberg, N., Friedmann, R., \& Asulin-Peretz, L. (2011). Emotional and personality-related aspects of career decision-making difficulties: Facets of career indecisiveness. Journal of Career Assessment, 19(1), 3-20. https://doi.org/10.1177/1069072710382525

Guan, M., Capezio, A., Restubog, S. L. D., Read, S., Lajom, J. A. L., \& Li, M. (2016). The role of traditionality in the relationships among parental support, career decision-making self-efficacy and career adaptability. Journal of Vocational Behavior, 94, 114-123. https://doi.org/10.1016/j.jvb.2016.02.018

Iliescu, D. (2018). What Is Test Adaptation?Adapting Tests in Linguistic and Cultural Situations. https://doi.org/10.1017/9781316273203.003

Kuçuk, S., Habaci, M., Gokturk, T., Urker, A., \& Adiguzelli, F. (2012). Role of Family , Environment and Educat on on the Personal ty Development, 12(8), 1078-1084. https://doi.org/10.5829/idosi.mejsr.2012.12.8.66 21

Lei, Y. C. (2013). The Big Five Model of Personality and Career Development. Texas A\&M University.

Nababan, M., Nuraeni, A., \& Sumardiono. (2012). Pengembangan model penilaian kualitas terjemahan. Kajian Linguistik Dan Sastra, 24(1), 39-57. Retrieved from https://publikasiilmiah.ums.ac.id/bitstream/hand le/11617/2220/4. MANGATUR NABABAN.pdf; sequence $=1$

Pečjak, S., \& Košir, K. (2007). Personality, motivational factors and difficulties in career decision-making in secondary school students. Psihologijske Teme, 16(1), 141-158. https://doi.org/159.923-057.874 159.947.5057.87437 .048 .4

Penn, L. T. (2016). Testing the Joint Roles of Career Decision Self-Eficacy and Personality Traits in the Prediction of Career Indecision. University of Maryland.

Purnamasari, D. S. S. P. (2015). Tingkat Kematangan Karir Siswa Kelas VIII SMP Islam Sudirman Ambarawa. Widya Sari, 17(2), 1-7.

Purwanta, E. (2011). MODEL EKSPLORASI KARIER SISWA SLTP DI KABUPATEN KLATEN TAHUN 2010. Universitas Negeri Malang.

Rina, S. (2015). Jajak Pendapat App. Retrieved April 24, 2018, from https://blog.jakpat.net/kuliahdimana-survei-pilihan-universitas-murid-smasmp-indonesia/

Rogers, M. E., Creed, P. A., \& Glendon, A. I. (2008). The role of personality in adolescent career planning and exploration: A social cognitive perspective. Journal of Vocational Behavior, $73(1)$, 132-142. https://doi.org/10.1016/j.jvb.2008.02.002

Sayekti. (1994). Bimbingan dan Konseling Keluarga. Yogyakarta: Mas Offset.

Su, M.-S., Chang, T.-C., Wu, C.-C., \& Liao, C.-W. (2016). Factors Affecting the Student Career Decision-Making of Junior High School Students in Central Taiwan Area. International 
Rossi Galih Kesuma, Dwi Yuwono Puji Sugiharto, Sunawan

Jurnal Bimbingan dan Konseling Ar-Rahman

Volume 4, Nomor 2, Tahun 2018

e-ISSN 2477-6300

Journal of Information and Education

Technology, 6(10), 843-850.

https://doi.org/10.7763/IJIET.2016.V6.803

Taylor, K. M., \& Betz, N. E. (1983). Applications of self-efficacy theory to the understanding and treatment of career indecision. Journal of Vocational Behavior, 22(1), 63-81. https://doi.org/10.1016/0001-8791(83)90006-4

Wang, N., Jome, L. M., Haase, R. F., \& Bruch, M. A. (2006). The role of personality and career decision-making self-efficacy in the career choice commitment of college students. Journal of Career Assessment, 14(3), 312-332. https://doi.org/10.1177/1069072706286474

Widiawati, A. I., \& Setyowani, N. (2016). Indonesian Journal of Guidance and Counseling. Indonesian Journal of Guidance and Counseling: Theory and Application, 5(1), 39-44. Retrieved from journal.unnes.ac.id/sju/index.php/jbk

Xing, X. (2016). Family Influences on Career Decision Making Self Efficacy of Secondary Vocational Students in China. University of Georgia.

Yulius, A. (2014). Kemantapan Pengambilan Keputusan Karir Siswa Kelas IX di SMP Negeri 9 Salatiga. Universitas Kristen Satya Wacana. Retrieved from http://repository.uksw.edu/handle/123456789/52 13

Zunker, V. G. (2006). Career Counselling A holistic Approach (7th Editio). USA: Thomson Brooks/Cole.

https://doi.org/10.1017/CBO9781107415324.00 4

Dipublikasikan Oleh :

UPT Publikasi dan Pengelolaan Jurnal

Universitas Islam Kalimantan Muhammad Arsyad Al-Banjari Banjarmasin 